\title{
Occurrence and molecular characterization of different virulence-associated genes of Cronobacter sakazakii isolates from some foods and dust samples
}

\section{Ülkü Demirci' ${ }^{*}$ (Issmail Hakkı Tekiner ${ }^{2}$ Burcu Çakmak $^{3}$ Haydar Özpınar ${ }^{4}$}

${ }^{1}$ Department of Food Safety and Nutrition, Institute of Natural \& Applied Sciences, Istanbul Aydın University, Istanbul, Turkey. E-mail: ulkudemirci@hotmail.com. "Corresponding author.

${ }^{2}$ Gastronomy Department, School of Applied Sciences, Istanbul Gelişim University, Istanbul, Turkey.

${ }^{3}$ Department of Nutrition and Dietetics, Health Sciences Faculty, Istanbul Esenyurt University, Istanbul, Turkey.

${ }^{4}$ Graduate School of Health Sciences, Istanbul Gedik University, Istanbul, Turkey.

ABSTRACT: Among the Cronobacter genus, Cronobacter sakazakii is the most common species posing a severe health risk for newborns, infants and children. Some infant formulas, cereal-based foods, and food production environments may be the potential reservoirs of $C$. sakazakii. This pathogen possesses different virulence factors encoded by different virulence genes. Therefore, characterizing these genes is important for distinguishing pathogenic strains from nonpathogenic ones. The objective of this study was to characterize some virulence genes [OmpA, OmpX, zpx, and Cpa] by real-time polymerase chain reaction (PCR) in C. sakazakii isolates from a total of 120 samples (20 each of milk powder, starch, rice flour, semolina, infant formula and dust samples from food production environments). Overall, 13 isolates (7 from milk powder, 2 rice flour, 1 semolina, and 3 dust) were cultured, identified by bioMérieux API ${ }^{\circledR} 20 E$ test kit, and then subjected to real-time PCR application for screening the target virulence-associated genes. Our results showed that all of 13 isolates were positive for the virulence genes OmpA, OmpX, zpx, and Cpa. In summary, our study revealed that some of the analyzed foods and environmental samples were contaminated with pathogenic C. sakazakii with its virulence-associated markers, far above the allowable limit; and therefore, this level of contamination may pose a severe health threat for newborns, infants, and children.

Key words: C. sakazakii, dust, food, health, virulence genes.

Ocorrência e caracterização molecular de diferentes genes associados à virulência de Cronobacter sakazakii detectados em alguns alimentos e amostras de poeira

RESUMO: Dentre o gênero Cronobacter, Cronobacter sakazakii é a espécie mais comum que representa um grave risco para a saúde dos recém-nascidos, bebês e crianças. Algumas formulas infantis paracrianças, alimentos a base de cereais e locais de produção de alimentos, foram considerados como potenciais locais de contaminação de C. sakazakii. Este patógeno possui diferentes agentes de virulência codificados por diferentes genes de virulência. Portanto, a caracterização dos genes é importante para distinguir as cepas patogênicas das não patogênicas. O objetivo deste estudo foi caracterizar os diferentes genes de virulência [OmpA, OmpX, zpx, and Cpa] em C. sakazakii isolados em um total de 120 amostras (20 de cada uma delas - leite em pó, amido, farinha de arroz, sêmola, comida para bebês e amostras de poeira provenientes dos ambientes de produção de alimentos) por reação em cadeia da polimerase em tempo real (RT-PCR). No total, foram cultivadas 13 estirpes (7 de leite em pó, 2 de farinha de arroz, 1 de sêmola e 3 poeiras) e depois identificadas pelo kit de teste bioMérieux API ${ }^{\circledR} 20 E$. As estirpes identificadas foram submetidas ao PCR em tempo real para caracterizar os genes alvo associados à virulência. Os resultados mostraram que todos os genes C. sakazakii isolados eram patogenicos e positivos às OmpA, OmpX, zpx e Cpa com um padrão de coexistência. Em resumo, o nosso estudo revelou que os alimentos e os ambientes de produção de alimentos analisados constituíam uma ameaça à saúde dos recémnascidos, bebês e crianças devido à contaminação por C. sakazakii patogênico como marcadores associados à virulência.

Palavras-chave: C. sakazakii, Poeira, alimentação, genes de virulência.

\section{INTRODUCTION}

Cronobacter sakazakii is an opportunistic pathogen with high mortality rates of $40-80 \%$. It causes severe infections, including necrotizing enterocolitis, bacteremia and meningitis, in newborns, infants, children up to three years of age, and immunocompromised adults less than 70 years (HEPERKAN et al., 2017).

Globally, very few surveillance data are available for $C$. sakazakii-related diseases because of the lack of available information on surveillance systems, which are rarely sufficient to examine exposure factors. The World Health Organization has identified roughly 120 individually documented cases of Cronobacter spp. infections among infants and young children up to three years of age (IVY et al., 2013). The collection of food borne pathogenic isolates is important for developing detection methods, intervention strategies, and an understanding of pathogenesis. Food borne disease surveillance 
and/or outbreak reporting systems encompassing C. sakazakii infection have been employed in most countries and the data by these systems suggested that very young infants are at a greater risk of severe disease and death from infection with this organism (FAO \& WHO, 2008).

Many studies have reported the presence of C. sakazakii in infant formula, follow-up formula, growing-up formula, children's formula, semolina, milk powder, starch, and rice flour (SHAKER et al., 2007; GÖKMEN et al., 2010; XU et al., 2014; YAN et al., 2015; LI et al., 2016; AKINEDEN et al., 2017), milk and whey powder (HEPERKAN et al., 2017), dairy products, sahlab, and dust samples (EL-SHAROUD et al., 2009; MÜLLER et al., 2013), herbs and spices (JARADAT et al., 2009), dried herbs and vegetables (OGIHARA et al., 2014) and frozen food, seafood, spices, and ready-to-eat snacks (MIRANDA et al., 2017).

Infant formulas and other cereal-based foods consumed by infants and young children must be free of this pathogen according to national and international authorities. In addition, C. sakazakii contamination has repeatedly been detected in factories processing baby foods and ingredients used for making baby foods (PARRA-FLORES et al., 2015). Dust particles in the air of such a facility may act as a vector of $C$. sakazakii dissemination. The higher levels of $C$. sakazakii are mostly observed in dust filters, vacuum cleaners, bagging, and packaging areas (FEI et al., 2015).

C. sakazakii is the most frequently isolated species of the Cronobacter genus. However, its virulence factors remain poorly studied (ALMAJED \& FORSYTHE, 2016). Therefore, their characterization is important for distinguishing pathogenic from nonpathogenic strains. An advanced understanding of this bacterium has begun to characterize the virulence factors and pathogenic potential of C. sakazakii. These developments have been obtained by improved DNA-based techniques (HUNTER \& BEAN, 2013). Recent studies have identified many virulence factors in C. sakazakii such as seven O-serogroups and eleven proteolytic enzymes (DU et al., 2015). Among the virulence-related proteins, outer membrane proteins $(O m p A$ and $O m p X)$ are involved in the colonization of the gastrointestinal tract and may have roles in helping the organism penetrate the blood-brain barrier (KYUMSON et al., 2010; ZIMMERMANN et al., 2014; ALMAJED \& FORSYTHE, 2016). The virulence factors Zinc-metalloprotease ( $z p x)$ causes cell deformation and cells rounding, other virulence factor Cronobacter plasminogen activator ( $\mathrm{Cpa})$ provides resistance against the bactericidal activity of serum, activates plasminogen, and inactivates alpha2antiplasmin (YE et al., 2016; ESHWAR et al., 2016).

The objective of this study was to characterize the different virulence genes (OmpA, $O m p X$, zpx, and $C p a$ ) in C. sakazakii isolates by realtime PCR from samples of each milk powder, starch, rice flour, semolina, infant formula and dust samples from food production environments.

\section{MATERIALS AND METHODS}

\section{Reference cultures}

As standardized cultures, C. sakazakii ATCC $^{\circledR} 29544$ (Liofilchem, Istanbul, Turkey) and $E$. coli ATCC ${ }^{\circledR} 25922$ (Liofilchem) were used for control testing in the phenotypic and genotypic methods.

\section{Sample collection}

During the period from 2015 to 2016,120 samples (20 each of milk powder, starch, rice flour, semolina, infant formula, and dust from dust collection systems in food production environments) were randomly collected from public bazaars, markets and food production environments in Istanbul, Turkey. Samples were placed in sterile sampling bags and then taken to the laboratory in a thermobox container at $4^{\circ} \mathrm{C}$ for further examinations.

\section{Sample preparation and microbiological analysis}

Samples were prepared in accordance with the Method "ISO 8261:2001 Milk and Milk Products General Guidance for the preparation of the test samples, initial suspensions, and decimal dilutions for microbiological examination". Isolation of the presumptive $C$. sakazakii species was performed according to the Guidelines of the Method "ISO/ TS 22964:2006 Milk and Milk Products-Detection of Enterobacter sakazakii". Of each sample, $25 \mathrm{~g}$ was homogenized in $225 \mathrm{~mL}$ of buffered peptone water (LAB103, UK) for 2 min using a stomacher (EasyMix-AES Chemunex, France). The homogenized suspension was then exposed to aerobic incubation at $37^{\circ} \mathrm{C}$ for $18 \mathrm{~h}$. Then, $100 \mu \mathrm{L}$ of the pre-enriched suspension was mixed with $10 \mathrm{~mL}$ of Modified Laurylsulfate-Tryptose Vancomycin (mLST/vancomycin) broth (Liofilchem). The inoculated plate was incubated at $44^{\circ} \mathrm{C}$ for $24 \mathrm{~h}$ under aerobic conditions. Of the incubated suspension, $10 \mu \mathrm{L}$ was streaked on Harlequin CSIM chromogenic selective media (LABM, UK) by using a sterile loop and allowed for incubation at $44^{\circ} \mathrm{C}$ for $24 \mathrm{~h}$. Fifteen blue-green colonies were selected for the 
confirmation and subcultured on a Tryptone soya agar plate (CM0131, Oxoid, Turkey), incubated at $37^{\circ} \mathrm{C}$ for $46 \mathrm{~h}$, and checked for yellow coloration. Finally, the subcultured isolates were subjected to the biochemical identification test.

\section{Biochemical identification}

The species identification of presumptive C. sakazakii isolates was conducted by $\mathrm{API}^{\circledR} 20 \mathrm{E}$ Test Kit (bioMérieux, France) according to the manufacturer's instructions. Readings were evaluated according to the criteria by the API Reading Scale. Finally, the identified isolates were stored in tryptic soy broth (LABM, UK) containing $10 \%$ glycerol at $-20^{\circ} \mathrm{C}$ until further workup.

\section{DNA extraction}

The plasmid DNA of the identified $C$. sakazakii isolates were extracted from the isolates refreshed on Luria-Bertani broth using the FastLyse Miniprep Kit (MDI Membrane Tech, Turkey). The extracted DNA was stored at $-20^{\circ} \mathrm{C}$ for further molecular analyses.

Real-time PCR primers for virulence genes and reaction conditions

The primer pairs of the virulence-related genes, OmpA, OmpX, zpx, and $C p a$, were prepared according CAI et al. (2013), AMALARADJOU et al. (2014), KOTHARY et al. (2007) and FRANCO et al. (2011), respectively (Table 1). All primers were designed by Exim Ltd. (Istanbul, Turkey) and Integrated DNA Technologies (Istanbul, Turkey). As standardized cultures, C. sakazakii ATCC $^{\circledR} 29544$ (Liofilchem) and E. coli $\mathrm{ATCC}^{\circledR} 25922$ (Liofilchem) were used for control testing. All real-time PCR analyses were conducted as a single-plex assay for amplifying $O m p A, O m p X, z p x$, and $C p a$. A typical PCR mixture, in a final volume of $18 \mu \mathrm{L}(0.6 \mu \mathrm{M}$ of each primer $[10 \mu \mathrm{M}], 10 \mu \mathrm{L}$ of $2 \mathrm{x}$ SYBR Green Master Mix [Analytik Jena, Turkey], and $6.8 \mu \mathrm{L}$ of DNase/ RNase-free water, was prepared. A total of $18 \mu \mathrm{L}$ of this prepared master mix solution was pipetted into each well after the addition of $2 \mu \mathrm{L}$ of extracted DNA. Each sample was run in duplicate. Sterile water was placed in the negative control well in place of DNA, and C. sakazakii $\mathrm{ATCC}^{\circledR} 29544$ and E. coli $\mathrm{ATCC}^{\circledR}$ 25922 DNA (in 2 wells) were used for control testing. FAM/SYBR ${ }^{\circledR}$ Green (Excitation: 492nm, Emission: $516 \mathrm{~nm}$ ) was used. Thermal processing conditions were optimized at the laboratory according to the primers used. To verify the specificity of the reactions using SYBR Green I as the fluorescent dye, melting curve analysis was performed. The analysis was performed using the Agilent Stratagene Mx3000P real-time PCR (Waldbronn, Germany). The sensitivity of the real-time PCR assay undergoing $\mathrm{Ct} \leq 40$ cycles of amplification was accepted to be positive in accordance with the melting point setting because of the interference of undesirable nonspecific amplifications (Table 1).

Table 1 - Primer design, sequences, and amplification conditions for virulence genes.

\begin{tabular}{|c|c|c|c|c|}
\hline Primer $\left(f / r^{*}\right)$ & Sequence & Amplicon (bp) & PCR & Reference \\
\hline $\begin{array}{l}\text { OmpA-f } \\
\text { OmpA-r }\end{array}$ & $\begin{array}{c}\text { 5'-GGT GAA GGA TTT AAC CGT GAA CTT-3' } \\
\text { 5'-GCG CCT CGT TAT CAT CCA AA-3' }\end{array}$ & 70 & PCR-1 & XIAN-QUAN CAI et al. (2013) \\
\hline $\begin{array}{l}O m p X-f \\
O m p X-\mathrm{r}\end{array}$ & $\begin{array}{c}\text { 5'-GTC TTT CAG CAC TGG CTT GTG T-3' } \\
\text { 5'-GGT GCC AGC AAC AGC AGA A-3' }\end{array}$ & 150 & PCR-2 & AMALARADJOU et al. (2014) \\
\hline $\begin{array}{l}z p x-\mathrm{f} \\
z p x-\mathrm{r}\end{array}$ & $\begin{array}{l}\text { 5'-GAA AGC GTA TAA GCG CGA TTC-3' } \\
\text { 5'- GTT CCA GAA GGC GTT CTG GT-3' }\end{array}$ & 350 & PCR-3 & KOTHARY et al. (2007) \\
\hline $\begin{array}{l}\text { Cpa-f } \\
\text { Cpa-r }\end{array}$ & $\begin{array}{c}\text { 5'-GCC TGG CGG AAT TCA ATG G-3' } \\
\text { 5'-GAT CAA AGC TGC AGT CAG AAA CG-3' }\end{array}$ & 936 & PCR-4 & FRANCO et al. (2011) \\
\hline
\end{tabular}

*f: forward and $\mathrm{r}$ : reverse.

PCR-1: 1 cycle for $2 \mathrm{~min}$ at $50^{\circ} \mathrm{C}, 1$ cycle for $10 \mathrm{~min}$ at $95^{\circ} \mathrm{C}$ followed by 40 cycles for $15 \mathrm{~s}$ at $95{ }^{\circ} \mathrm{C}$, and finally 1 cycle for $1 \mathrm{~min}$ at $60^{\circ} \mathrm{C}$.

PCR-2: 1 cycle for $2 \mathrm{~min}$ at $50^{\circ} \mathrm{C}, 1$ cycle for $10 \mathrm{~min}$ at $95^{\circ} \mathrm{C}$ followed by 40 cycles for $15 \mathrm{~s}$ at $95{ }^{\circ} \mathrm{C}$, and finally 1 cycle for $1 \mathrm{~min}$ at $60^{\circ} \mathrm{C}$.

PCR-3: 1 cycle for $15 \mathrm{~min}$ at $95^{\circ} \mathrm{C}$, followed by 35 cycles for $1 \mathrm{~min}$ at $95^{\circ} \mathrm{C}, 1 \mathrm{~min}$ at $62{ }^{\circ} \mathrm{C}, 1 \mathrm{~min}$ at $72^{\circ} \mathrm{C}$, and finally $1 \mathrm{cycle}$ for 7 min at $72^{\circ} \mathrm{C}$.

PCR-4: 1 cycle for $5 \mathrm{~min}$ at $95^{\circ} \mathrm{C}$, followed by 40 cycles for $15 \mathrm{~s}$ at $95^{\circ} \mathrm{C}, 15 \mathrm{~s}$ at $62^{\circ} \mathrm{C}$, and $30 \mathrm{~s}$ at $72^{\circ} \mathrm{C}$, and finally 1 cycle for $1 \mathrm{~min}$ at $95^{\circ} \mathrm{C}, 30 \mathrm{~s}$ at $55^{\circ} \mathrm{C}$, and $30 \mathrm{~s}$ at $95^{\circ} \mathrm{C}$. 


\section{RESULTS}

In this study, 13 C. sakazakii isolates (7 from milk powder, 2 rice flour, 1 semolina, and 3 dust) were cultured, and then identified by the bioMérieux API ${ }^{\circledR} 20 \mathrm{E}$ test kit. The identified strains were subjected to real-time PCR for characterizing the target virulence-associated genes. Our results showed that all of 13 isolates were positive for the virulence genes $O m p A, O m p X, z p x$, and $C p a$, revealing that some of the analyzed foods and environmental samples were contaminated with pathogenic C. sakazakii with its virulenceassociated markers, far above the allowable limit; and therefore, this level of contamination may pose a severe health threat for newborns, infants, and children (Table 2, Figure 1, 2, 3 and 4).

\section{DISCUSSION AND CONCLUSIONS}

The recorded history for Cronobacter spp. is short but they have certainly existed for millions of years. Cronobacter (Formerly Enterobacter sakazakii) is a newly classified genus including seven species $(C$. sakazakii, C. malonaticus, C. turicensis, C. muytjensii, C. dubliniensis, C. condimenti, and C. universalis) (SINGH et al., 2015). Among them, C. sakazakii is the most common and most often isolated species with high mortality rates of $40-80 \%$ in infants, children, and adults especially elderly and immunocompromised adults (HEPERKAN et al., 2017).

This opportunistic microorganism is unique in the Cronobacter genus in encoding genes enabling the use of some clinically significant exogenous substances such as sialic acid, which is a major evolutionary host adaptation, as the compound present in breast milk and infant foods (JOSEPH et al., 2012). In the last few years, much has been learned about the complexity of $C$. sakazakii since being first described as Enterobacter sakazakii in 1980 (SHASHKOV et al., 2015). However, many uncertainties are associated with the assessment of the public health risk posed by this pathogen (HEALY et al., 2010; BAO et al., 2017). Disease surveillance and/or outbreak reporting systems encompassing $C$. sakazakii infection have suggested that infants and children are at a higher risk of severe disease and death from the infection with food borne $C$. sakazakii (FAO \& WHO, 2008). Our study proved that the foods and food production environments analyzed posed a health threat for newborns, infants, and children because of contamination by $C$. sakazakii.

International studies conducted between 2008 and 2014 have indicated that $5.7 \%$ of the food samples of animal origin and $19 \%$ of plant origin harbored Cronobacter spp., including C. sakazakii (SANI \& ODEYEMI, 2015). Another study in the Czech Republic showed that the foods of plant origin were most frequently contaminated with $C$. sakazakii (54.7\%) (HOCHEL et al., 2012). However, in our study, only $35 \%$ of $C$. sakazakii strains were isolated from milk powder samples, followed by dust, rice flour, and semolina samples. Our findings suggest that infants and children are at a risk of disease and death from infection with the analyzed foods and environmental sources harboring $C$. sakazakii.

In Jordan, SHAKER et al. (2007) and JARADAT et al. (2009) detected C. sakazakii in infant formulas $(1.4 \%$ to $17.4 \%)$ and semolina samples, while another study conducted in Egypt reported the organism in milk powder and infant formula samples (EL-SHAROUD et al., 2009). XU et al. (2014) and

Table 2 - Occurrence of $C$. sakazakii isolates and their virulence genes in the sampling groups.

\begin{tabular}{|c|c|c|c|c|c|c|c|}
\hline Sample & No. of sample (n) & No of $C$. sakazakii + sample (n,\%) & No of virulent + isolate $(n, \%)$ & OmpA & OmpX & $z p x$ & Cpa \\
\hline Starch & 20 & $0(0 \%)$ & $0(0 \%)$ & - & - & - & - \\
\hline Infant formula & 20 & $0(0 \%)$ & $0(0 \%)$ & - & - & - & - \\
\hline Semolina & 20 & $1(5 \%)$ & $1(100 \%)$ & + & + & + & + \\
\hline Rice flour & 20 & $2(10 \%)$ & $2(100 \%)$ & + & + & + & + \\
\hline Dust & 20 & $3(15 \%)$ & $3(100 \%)$ & + & + & + & + \\
\hline Milk powder & 20 & $7(35 \%)$ & $7(100 \%)$ & + & + & + & + \\
\hline Total & 120 & $13(11 \%)$ & $13(100 \%)$ & + & + & + & + \\
\hline
\end{tabular}

The numbers in parentheses represent percentage values. 


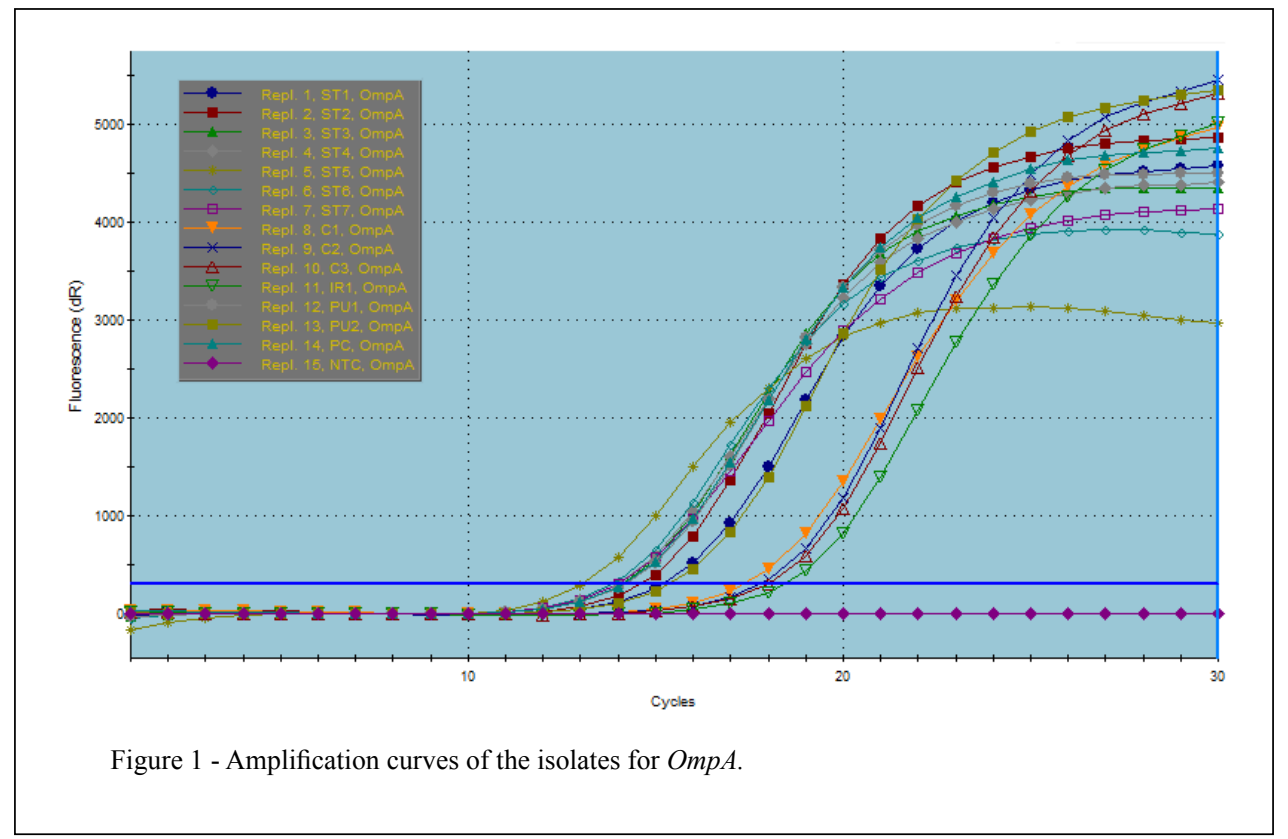

HUANG et al. (2015) found this opportunistic organism in general formula $(6.25 \%)$, infant formula $(1.82 \%$ to $16.9 \%)$, follow-up formula $(3.64 \%)$, growing-up formula $(5.45 \%)$, children's formula $(2.5 \%)$, and rice flour $(28.8 \%)$ consumed in China between 2010 and 2012. Milk powder, rice flour, and semolina are widely used as ingredients for producing various infant and children foods. Level of contamination with C. sakazakii was higher in the analyzed milk powder samples in this study than in international studies but was lower in semolina and rice flour samples compared with results obtained by JARADAT et al.

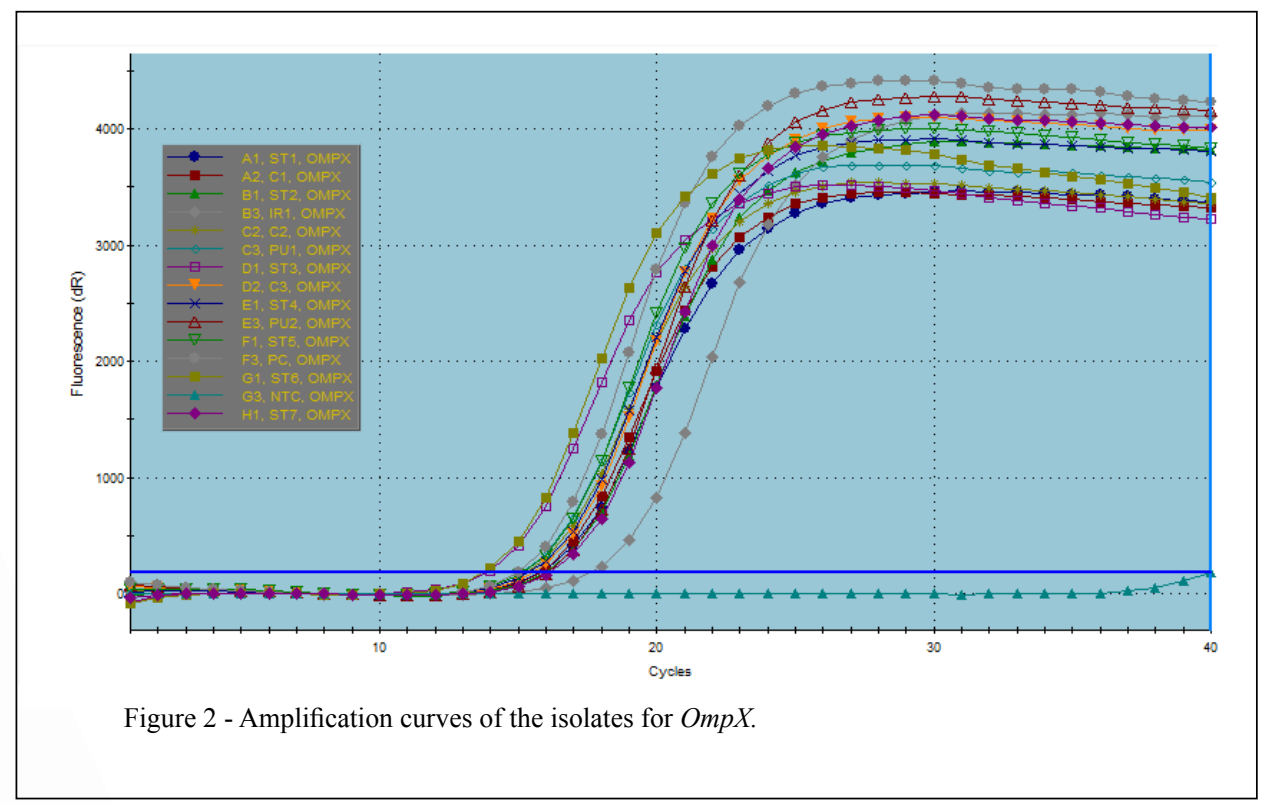

Ciência Rural, v.48, n.8, 2018. 


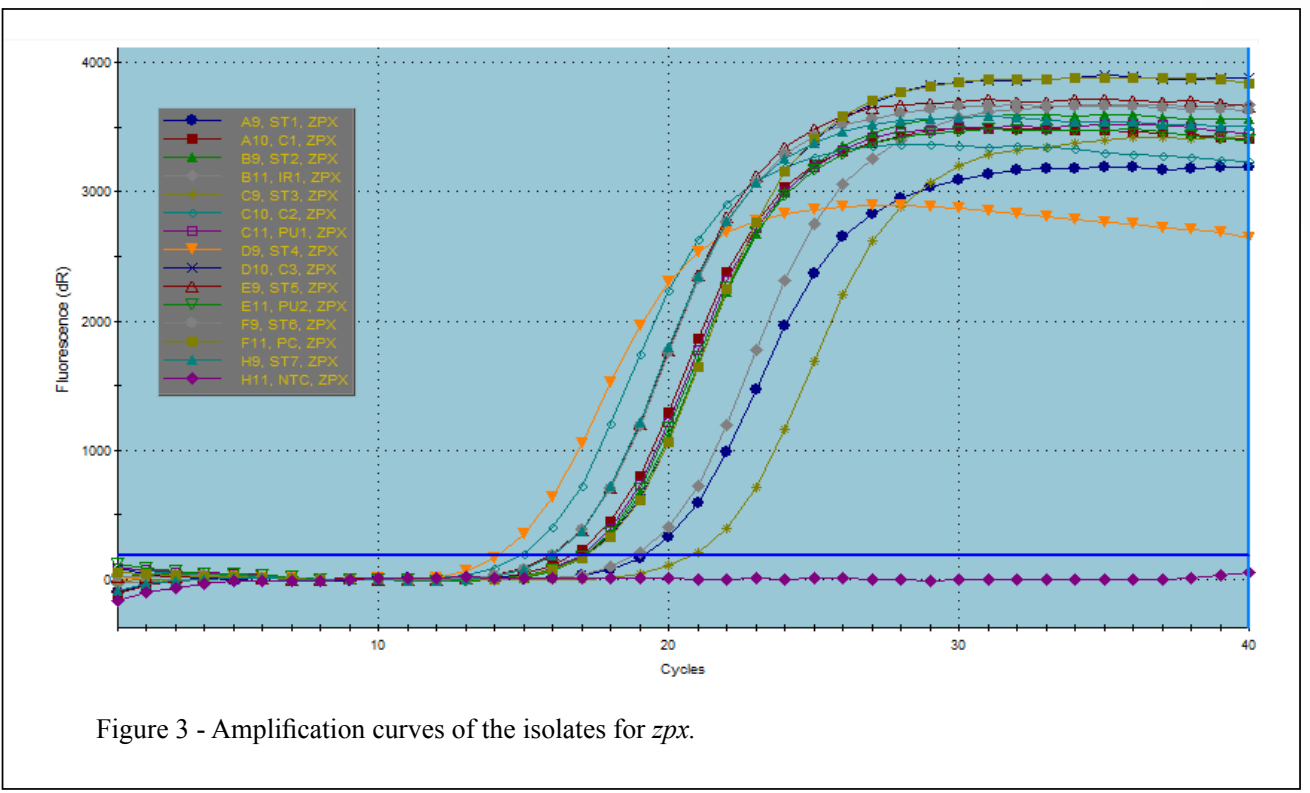

(2009) and XU et al. (2014). By contrast, C sakazakii was not detected in starch and infant formula samples in this study. The results presented in this assay were similar to those obtained by MIRANDA et al. (2017) in the United States of America and by HOCHEL et al. (2012) in the Czech Republic.
In Turkey, some studies have provided significant data for the frequency of Cronobacter spp., especially $C$. sakazakii, in different sources. C. sakazakii was reported in milk powder $(5 \%$ to $7.5 \%)$, starch $(5 \%)$, rice flour $(5 \%)$, semolina $(5 \%)$, and whey powder samples $(7.5 \%)$ (GÖKMEN et al.,

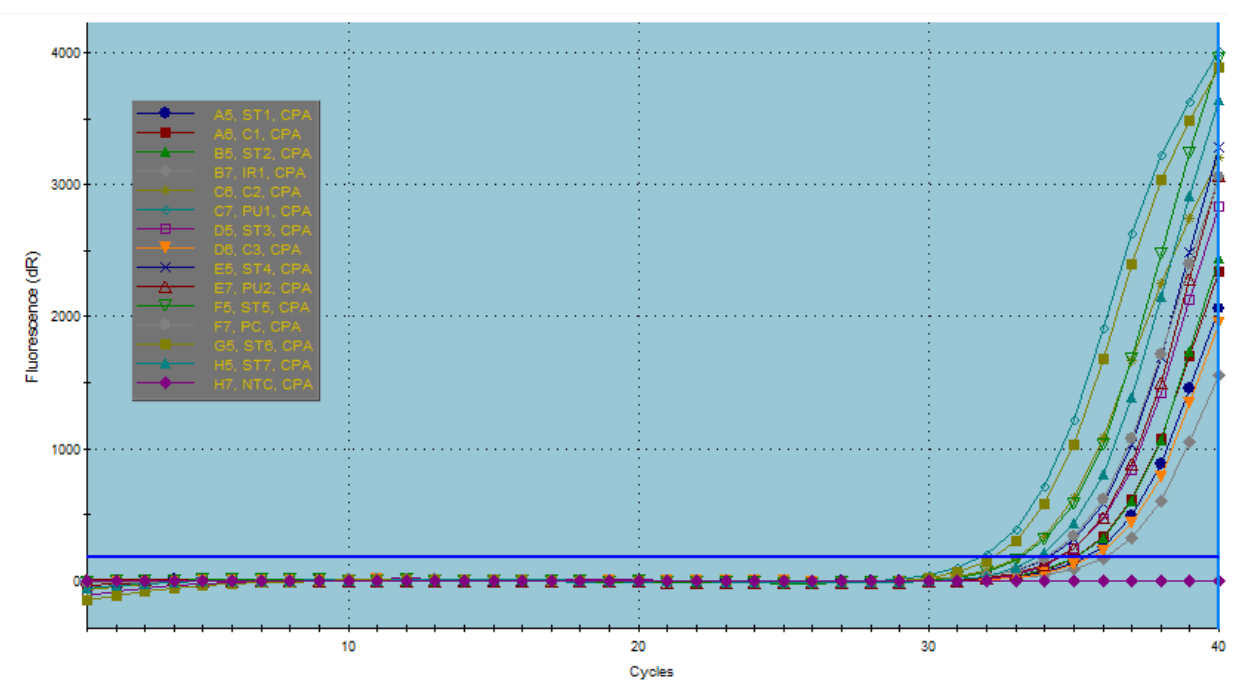

Figure 4 - Amplification curves of the isolates for Cpa. 
2010; CAVA GÜMÜȘ et al., 2017; HEPERKAN et al., 2017); but whey powder and powdered infant formulas from three retail brands did not contain the organism (GÖKMEN et al., 2010; GÜNER et al., 2011). Results obtained in this study showed that milk powder, rice flour, and semolina were important sources of $C$. sakazakii posing a health risk for infants and children.

In Jordan, the frequency of $C$. sakazakii reported in vacuum dust of a food production facility was $18 \%$, C. sakazakii has also been isolated from food production areas (SHAKER et al. 2007; JANINE, 2015). MÜLLER et al. (2013) showed that C. sakazakii was the most prevalent species identified $(93.6 \%)$ in a facility processing powdered infant formula in Switzerland. Similarly, MOZROVÁ et al. (2014) reported the organism in samples from a dairy farm and dust from vacuum cleaners in the Czech Republic. For instance, textile filters for exhaust air of spray-drying towers in a milk powderproducing plant were found to be internal reservoirs of C. sakazakii. This situation occurs because of economic reasons, the waste powder from the filters is reintroduced into the product flow for optimization and cost-reduction goals in the production cycle (JACOBS et al., 2011). To lower the contamination risk by $C$. sakazakii in the production area, air humidity and the number of dust particles in the air should be kept minimal and production equipment should be frequently cleaned and waste powder should be effectively treated (FEI et al., 2015). In this study, $25 \%$ of the analyzed dust samples were positive for C. sakazakii. Future studies would discover the impact of the production area and equipment as risk factors on the dissemination of $C$. sakazakii and create methods to better control this pathogen and reduce its infections.

The virulence factors indicate the pathogenic potential of $C$. sakazakii with their plausible connection with clinical manifestations, including meningitis and necrotizing enterocolitis in infants, and septicemia and catheter-associated infections in elderly and immunocompromised people (SINGH et al., 2017). However, the virulence factors and the pathogenesis of C. sakazakii infection are poorly understood. Therefore, toxicological experiments, C. sakazakii subtyping, molecular and proteomics analyses comprehensively evaluate the virulence-related characteristics of $C$. sakazakii. The detection of Cronobacter spp. according to ISO/TS 22964 takes up to a week, and traditional methods do not provide information about the virulence potential of a strain. Because of this reason, fast and sensitive methods as mentioned above are required (YAN et al., 2012). For instance, the outer membrane protein $O m p A$, a potential virulence factor involved in the crossing of the blood-brain barrier before the onset of meningitis, has been used for identification purposes (FEI et al., 2015). OmpA works synergistically with some other virulence genes in vitro and in vivo in the pathogenesis of $C$. sakazakii infection (CHANDRAPALA et al., 2014). Recent studies also have revealed that there are also other proteins having virulence-related potential. This situation simply indicates that Cronobacter virulence is dependent on multiple factors (JARADAT et al., 2009).

In last few years, many studies have examined the virulence characteristics of C. sakazakii isolated from a wide range of sources. A study showed that 13 isolates from a powdered infant formula factory harbored the virulence gene $z p x$, while no isolate contained OmpA (JARADAT et al., 2009) Another study revealed that $\mathrm{OmpA}$ was reported in $64.7 \%$ of Cronobacter strains tested in low-moisture food products, including powdered infant formulas (YAN et al., 2011). Similarly, $O m p A$ and $O m p X$ were reported in all Cronobacter spp., whereas $98 \%$ of Cronobacter strains possessed Cpa (JARADAT et al., 2009). Studies in Germany have revealed that $11 \%$ of C. sakazakii isolates from infant and baby foods were highly virulent (ZIMMERMANN et al., 2014; AKINEDEN et al., 2017). In a milk powder factory in China, the prevalance of virulence genotypes carrying Cpa-OmpX was $79.3 \%$ (WANG et al., 2015). Similarly, C. sakazakii isolates isolated from milk-based infant and baby food samples between 2010 and 2012 in China harbored mostly OmpA (LI et al., 2016). Another study showed that $C$. sakazakii isolates derived from plant-based materials and environmental samples harbored mainly $\mathrm{OmpA}$, followed by $\mathrm{Cpa}(60 \%)$ (SINGH et al., 2017). In this study, the isolated strains harbored all four virulence genes, OmpA, OmpX, zpx, and $C p a$, simultaneously. Studies are needed to determine the conditions that influence survival and growth or cause death of $C$. sakazakii in a broad range of locations. Differences in the hygiene and storage conditions are major key factors on the variations of the results. Also, culturebased methods are time-consuming as well as having insufficient effectiveness of virulence factors in bacteria.

This is the first comprehensive report in Turkey with characterization of some virulence genes in C. sakazakii isolates, and this led to develop a better understanding of its virulence characteristics mainly from infant and baby foods, and production areas of these foods. The literature showed that there is not adequate data in this field in Turkey. Overall, 
our study revealed that some of the analyzed foods and environmental samples were contaminated with pathogenic $C$. sakazakii with its virulenceassociated markers, far above the allowable limit; and therefore, this level of contamination may potentially pose a severe health threat for newborns, infants, and children.

\section{ACKNOWLEDGEMENTS}

The authors thank Haluk Camcı and Muhammet Gökçe from Ex-Im Healthcare Ltd. for their personal assistance in experimental studies.

\section{DECLARATION OF CONFLICTING OF INTERESTS}

The authors declared no potential conflicts of interest with respect to the research, authorship, and/or publication of this article.

\section{REFERENCES}

AKINEDEN, Ö. et al. Reassessment of Cronobacter spp. originally isolated as Enterobacter sakazakii from infant food. Food Microbiol, 65: 44-50, 2017. doi: 10.1016/j.fm.2017.01.021.

ALMAJED, F.S.; FORSYTHE, S.J. Cronobacter sakazakii clinical isolates overcome host barriers and evade the immune response. Microb Pathog, 90: 55-63, 2016. doi: 10.1016/j. micpath.2015.11.014.

AMALARADJOU, M.A. et al. Sub-inhibitory concentrations of trans-cinnamaldehyde attenuate virulence in Cronobacter sakazakii in vitro. Int J Mol Sci, 15; 8639-8655, 2014. doi: 10.3390/ijms 15058639 .

$\mathrm{BAO}, \mathrm{X}$. et al. Analysis on pathogenic and virulent characteristics of the Cronobacter sakazakii strain BAA-894 by whole genome sequencing. Microb Pathog, 109: 280-286, 2017. doi: 10.1016/j. micpath.2017.05.030.

CAI, X.Q. et al. Rapid detection and simultaneous genotyping of Cronobacter spp. (formerly Enterobacter sakazakii) in powdered infant formula using real-time PCR and high resolution melting (HRM) analysis. PLoS ONE, 8:e67082, 2013. doi: 10.1371/journal.pone.0067082.

CAVA GÜMÜŞ, P. et al. Investigation of extended spectrum B-lactamases (ESBL)-producing Enterobacteriaceae and Cronobacter Spp in infant formulas and cereal-based foods for children. IGUSABDER, 1: 19-32, 2017.

CHANDRAPALA, D. et al. Putative Inv is essential for basolateral invasion of Caco-2 cells and acts synergistically with OmpA to affect in vitro and in vivo virulence of Cronobacter sakazakii ATCC 29544. Infect Immun, 82: 1755-1765, 2014. doi: 10.1128/IAI.01397-13.

DU, X.J. et al. Comparative proteomic analysis of Cronobacter sakazakii isolates with different virulences. J Proteomics, 128: 344-351, 2015. doi: 10.1016/j.jprot.2015.08.013.
EL-SHAROUD, W.M. et al. Characterization of Cronobacter recovered from dried milk and related products. BMC Microbiol, 9: 24, 2009. doi: 10.1186/1471-2180-9-24.

ESHWAR, A.K. Linking genomo- and Pathotype: Exploiting the Zebrafish Embryo Model to Investigate the Divergent Virulence Potential among Cronobacter spp. PLoS One, 11: e0158428, 2016. doi: 10.1371/journal.pone.0158428.

FAO \& WHO. Enterobacter sakazakii (Cronobacter spp.) in powdered follow-up formulae. Microbiological Risk Assessment Series. No. 15. Rome. 90pp, 2008. Available from: <http://www.who.int/foodsafety>.

FEI, P. et al. Genotyping and source tracking of Cronobacter sakazakii and C. malonaticus isolates from Ppwdered infant formula and an infant formula production factory in China. Appl Environ Microbiol, 81: 5430-5439, 2015. doi:10.1128/AEM.01390-15.

FRANCO, A.A. et al. Cpa, the outer membrane protease of Cronobacter sakazakii, activates plasminogen and mediates resistance to serum bactericidal activity. Infect Immun, 79: 15781587, 2011. doi: 10.1128/IAI.01165-10.

GÖKMEN, M. et al. Presence of Enterobacter sakazakii in milk powder, whey powder and white cheese produced in Konya. Kafkas Univ Vet Fak Derg, 16 (Suppl-A):163-166, 2010. doi: $10.9775 / \mathrm{kvfd} .2010 .2801$.

GÜNER, A. et al. An investigation on the prevalence of Cronobacter sakazakii in powdered infant formula consumed in Turkey. J Food Agric Environ, 9: 82-84, 2011.

HEALY, B. et al. Cronobacter (Enterobacter sakazakii): an opportunistic foodborne pathogen. Foodborne Pathog Dis, 7: 339-350, 2010. doi: 10.1089/fpd.2009.0379.

HEPERKAN, D. et al. Cronobacter sakazakii in baby foods and baby food ingredients of dairy origin and microbiological profile of positive samples. Lebenson Wiss Technol, 75: 402-407, 2017. doi: 10.1016/j.lwt.2016.09.013.

HOCHEL, I. et al. Occurrence of Cronobacter spp. in retail foods. J Appl Microbiol, 112: 1257-1265, 2012. doi: 10.1111/j.13652672.2012.05292.x.

HUNTER, C.J.; BEAN, J.F. Cronobacter: An emerging opportunistic pathogen associated with neonatal meningitis, sepsis and necrotizing enterocolitis. J Perinatol, 33: 581-585, 2013. doi: 10.1038/jp.2013.26.

IVY, R.A. et al. International Life Science Institute North America Cronobacter (Formerly Enterobacter sakazakii) isolate set. J Food Prot., 6: 40-51, 2013. doi: 10.4315/0362-028X.JFP-11-546.

ISO 8261:2001 Milk and milk products -- General guidance for the preparation of test samples, initial suspensions and decimal dilutions for microbiological examination.

ISO/TS22964:2006(E) - Milk and milk products-detection of Enterobacter sakazakii Technical specification. Available from: $<$ https://www.iso.org/obp/ui/\#iso:std:iso:ts:22964:ed-1:v1:en>.

JACOBS, C. et al. Reservoir and routes of transmission of Enterobacter sakazakii (Cronobacter spp.) in a milk powder-producing plant. J Dairy Sci, 94: 3801-3810, 2011. doi: 10.3168/jds.2011-4318. 
JANINE, J. The Roles of epidemiologists, laboratorians, and public health agencies in preventing invasive Cronobacter infection. Front Pediatr, 3: 110, 2015. doi: 10.3389/fped.2015.00110.

JARADAT, Z.W. et al. Isolation of Cronobacter spp. (formerly Enterobacter sakazakii) from infant food, herbs and environmental samples and the subsequent identification and confirmation of the isolates using biochemical, chromogenic assays, PCR and 16S rRNA sequencing. BMC Microbiol, 9: 225, 2009. doi: 10.1186/1471-2180-9-225.

JOSEPH, S. et al. Comparative analysis of genome sequences covering the seven Cronobacter species. PLoS One, 7: e49455, 2012. doi: 10.1371/journal.pone. 0049455 .

KOTHARY, M.H. et al. Characterization of the zinc-containing metalloprotease encoded by zpx and development of a speciesspecific detection method for Enterobacter sakazakii. Appl Environ Microbiol, 73:: 4142-4151, 2007. doi: 10.1128/ aem.02729-06.

KYUMSON, K. et al. Outer Membrane Proteins A (OmpA) and $\mathrm{X}(\mathrm{OmpX})$ Are Essential for Basolateral Invasion of Cronobacter sakazakii. Appl Environ Microbiol, 76: 5188-5198, 2010. doi: 10.1128/AEM.02498-09.

LI, Z. et al. Prevalence and characterization of Cronobacter sakazakii in retail milk-based infant and baby foods in Shaanxi, China. Foodborne Pathog Dis, 4: 221-227, 2016. doi: 10.1089/ fpd.2015.2074.

MIRANDA, N. et al. Molecular Surveillance of Cronobacter spp. Isolated from a Wide Variety of Foods from 44 Different Countries by Sequence Typing of $16 \mathrm{~S}$ rRNA, rpoB and O-Antigen Genes. Foods, 6: E36,2017. doi: 10.3390/foods6050036.

MOZROVÁ, V. et al. Surveillance and characterisation of Cronobacter spp. in Czech retail food and environmental samples. Folia Microbiol (Praha), 59: 63-68, 2014. doi: 10.1007/s12223-013-0266-2.

MÜLLER, A. et al. Genetic diversity of Cronobacter sakazakii isolates collected from a Swiss infant formula production facility. J Food Prot, 76: 883-887, 2013. doi: 10.4315/0362028X.JFP-12-521.

OGIHARA, H. Cronobacter spp. in commercially available dried food in Japan. Biocontrol Sci, 19: 209-213, 2014. doi: 10.4265/bio.19.209.

PARRA-FLORES, J. Investigation on the Factors Affecting Cronobacter sakazakii Contamination Levels in Reconstituted Powdered Infant Formula. Front Pediatr, 3: 72, 2015. doi: 10.3389/fped.2015.00072.

SANI, N.A.; ODEYEMI, O. Occurrence and prevalence of Cronobacter spp. in plant and animal derived food sources: a systematic review and meta-analysis. Springerplus, 4: 545, 2015. doi: $10.1186 / \mathrm{s} 40064-015-1324-9$.

SHAKER, R. et al. Isolation of Enterobacter sakazakii and other Enterobacter spp. from food and food production environments. Food Control, 18: 1241-1245, 2007. doi:10.1016/j. foodcont.2006.07.020.

SHASHKOV, A.S. et al. Structural and genetic relationships of closely related O-antigens of Cronobacter spp. and Escherichia coli: C. sakazakii G2594 (serotype O4)/E. coli $\mathrm{O} 103$ and $C$. malonaticus G3864 (serotype O1)/E. coli O29. Carbohydr Res, 404: 124-131, 2015. doi: 10.1016/j.carres.2014.11.014.

SINGH, N. et al. Insights into virulence factors determining the pathogenicity of Cronobacter sakazakii. Virulence, 6: 433-440, 2015. doi: 10.1080/21505594.2015.1036217.

SINGH, N. et al. Profiling of Virulence Determinants in Cronobacter sakazakii Isolates from Different Plant and Environmental Commodities. Curr Microbiol, 74: 560-565, 2017. doi: 10.1007/s00284-017-1219-9.

WANG, Q. et al. Isolation, identification, virulence genes detection and antimicrobial susceptibility test of Enterobacter sakazakii in goat milk powder production process. Zhongguo Shipin Xuebao, 15: 175-181, 2015. doi: 10.16429/j.1009-7848.2015.05.023.

$\mathrm{XU}, \mathrm{X}$. et al. Occurrence and characterization of Cronobacter spp. in powdered formula from Chinese retail markets. Foodborne Pathog Dis, 11: 307-312, 2014. doi: 10.1089/fpd.2013.1657.

YAN, H. et al. Occurrence and Characterization of Cronobacter spp. in Dehydrated Rice Powder from Chinese Supermarket. PLoS ONE, 10: e0131053, 2015. doi: 10.1371/journal.pone.0131053.

YAN, Q.Q. et al. Cronobacter species (formerly known as Enterobacter sakazakii) in powdered infant formula: a review of our current understanding of the biology of this bacterium. J Appl Microbiol, 113: 1-15, 2012 . doi: 10.1111/j.13652672.2012.05281.x.

YAN, X. et al. Comprehensive Approaches to Molecular Biomarker Discovery for Detection and Identification of Cronobacter spp. (Enterobacter sakazakii) and Salmonella spp. Appl Environ Microbiol, 77: 1833-1843, 2011. doi: 10.1128/ AEM.02374-10.

YE, Y. et al. Identification of potential virulence factors of Cronobacter sakazakii isolates by comparative proteomic analysis. Int J Food Microbiol, 217: 182-188, 2016. doi: 10.1016/j. ijfoodmicro.2015.08.025.

ZIMMERMANN, J. et al. Development of a rapid detection system for opportunistic pathogenic Cronobacter spp. in powdered milk products. Food Microbiol, 42: 19-25, 2014. doi: 10.1016/j. fm.2014.02.010. 